\title{
Game Utilization as a Media to Train the Balance of Left and Right Brain
}

\author{
Evan Wijaya
}

Unika Soegijapranata

Semarang, Indonesia

mahha_lolicon@yahoo.com

\begin{abstract}
Human has two brain hemispheres, left hemisphere and right hemisphere. Left hemisphere is used for processing language, words, numbers, equations, etc. Right hemisphere is used for processing creativity, imagination, music, color, etc. Every human should have balance between left and right hemisphere. One method that could be used for balancing brain hemispheres is to use left and right hands for using tools, writing, or typing. "Typing Rhythm" is a game for PC platform, the purpose of this game is for brain balancing exercise by typing lyric of a song while the song is played.
\end{abstract}

Keywords- Game, Brain Balancing, Brain Hemispheres, Typing Rhythm

\section{INTRODUCTION}

Human has two brain hemispheres, left hemisphere and right hemisphere. Left hemisphere is used for processing language, words, numbers, equations, etc. Right hemisphere is used for processing creativity, imagination, music, color, etc. Someone with balanced brain will able to balance in every aspect of his/her life [1].

There are multiple ways to brain balancing such as Brain Gym, Tai Chi, Yoga, swimming, skiing, singing, dancing, playing musical instruments/ piano, typing, etc. [2], [3]. Brain Gym is a simple movement activity for balancing the use of left and right brain hemispheres.

However, the exercises of Brain Gym are boring if we do it monotonous and repeatedly without any challenge.

One innovation that can be used is by integrating the use of left and right hand with a video game with music genre. It is expected that the player will be more interested typing lyric from songs they like while balancing their brain hemispheres.
Assuming typing with 10 fingers is the same as doing Brain Gym because involving the use of both left and right hands.

The challenge from this game is with typing lyric using various tempo, from slow paced until fast paced songs. In this game the player should type the lyric fast and correctly, soautomatically they are doing Brain Gym exercise.

\section{LITERATURE REVIEW \\ 2.1 Brain \\ 2.1.1 Left Brain}

Left brain is a conscious mind, educative, positive and negative emotion. As if we see a cloud with shape of a frog, we still recognize it as a cloud and not a frog. When reading a storybook and imagine many things, we still recognize if we actually just seeing words [4].

Left brain is a short-term memory; the function of left brain is for controlling IQ (Intelligence Quotient) such as analytical, numbers, language, equations, linear, logic, mathematic, differences, structural, words, sequence, and step by step [5].

\subsubsection{Right Brain}

Right brain is an unconscious mind, where creativity came from. This part, which makes you visualize a frog when seeing a frog-shaped cloud, visualizes beach or forest when listening to music. We could imagine a person by reading description from a book [4].

Right brain is long-term memory; the function is for controlling EQ (Emotional Quotient) related with shape, emotion, imagination, creativity, music, similarity, and color [5].

\subsubsection{Benefit of Using Brain Hemispheres Equally}


Using both brain hemispheres equally gives benefit. For example when writing an essay, left brain often distracts when writing by criticizing your essay, and also checks the words whether there is misspelling or not. It's useful when reviewing the essay, not when writing the essay. When creating draft, it's better using right brain which gives inspiration and ideas, after finish writing a draft we use the left side of brain for review [6].

If both brain hemispheresare used equally.That person not only will be good at academic but also will affect in their social life [5].

\subsubsection{Way to Balance Brain Hemispheres}

Physical movements with crossing principle can be used for balancing brain hemispheres. Brain Gym derived from simple movements with intention to unify body and mind. Brain Gym belongs to EduKinestetics which is a science which studying body movement and connection between muscle and brain. Some purposes of Brain Gym include: to improve reading and writing skill, to increase confidence, to coordinate, to make communication, to focus on concentration, to memorize, to be hyperactivity, to relieve stress, to give motivation, and to develop personality, organization skills, and appearance [2].

Activity which involves the use of both hands such as typing or playing piano can be used as involving both left and right hemispheres [3].

\subsubsection{Connectionbetween Brain and Music}

Music involves many parts of brain, for example when a sound comes to ear, that sound enters the auditory cortex in temporal lobe. Temporal lobe located in non-dominant part of the brain (mostly in right hemisphere) listening tone, melody, harmony, beat, and long term beat (merge all of them into one part). In the other side, temporal lobe in dominant part of the brain (mostly in left hemisphere) better in analyzing sound, such as lyric, rhythm change, frequency, intensity, and harmony. Frontal lobe merge sound and thought then stimulate emotion (in limbic system) and past memories (from memories in whole brain), and cerebellum involved for counting beat (spatial aspect) [7]. Using scan PET (Positron Emission Tomography), Eric Jensen, and some educators found some different parts from brain which was activated by some aspects when listening to music. For example, rhythm activates Broca's area and cerebellum. Melody activates both hemispheres (But mostly shown in right hemisphere). Harmony activates left hemisphere together with outer inferior temporal. Tone activates left behind hemisphere and also outer auditory cortex on right hemisphere. And timbre activates right hemisphere [7].

\section{RESEARCH METHODOLOGY}

\subsection{Flowchart}

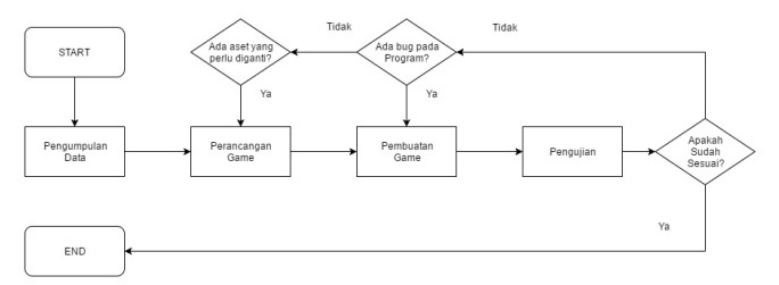

Figure 3.1 Flowchart

It started with collecting data. Game design is under sketch and sounds chosen will be used for the game. After the game is completed, then it will be tested to some tester.If there is bug or error, it will be rechecked and fixed.

\subsection{Collecting Data}

There were 2 steps of collecting data. The first one was collecting data for songs, the songs which would be used is from openings / endings from old Japanese anime which was already dubbed in Indonesian language, and some infamous Indonesian songs. The criteria of songs were short duration and type able lyric. The second one was collecting data for game design by doing survey or pretest. The subjects for this test are 98 people either male or female with average age 22 years old. 
3.2.1Do you ever heard or know about Brain Gym?

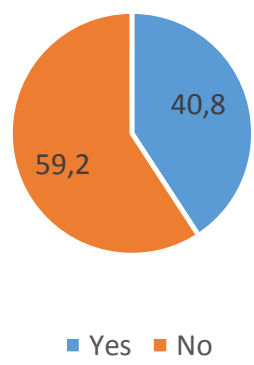

Figure 3.2 Diagram Pre-Test 1

From 98 people, 59.2 percent (58 people) answers never heard about Brain Gym.

\subsubsection{How often do you do Brain Gym?}

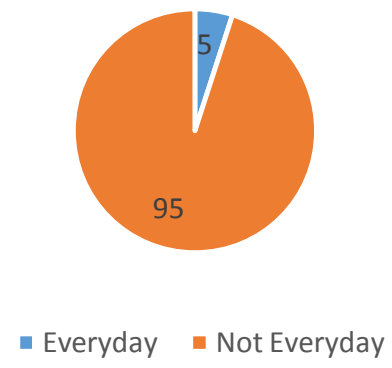

Figure 3.3 Diagram Pre-Test 2

From 40 people who ever heard about Brain Gym, 95 percent (38 people) answers didn’t do Brain Gym exercise every day.

3.2.3 Why don'tyou do Brain Gym Exercise every day?

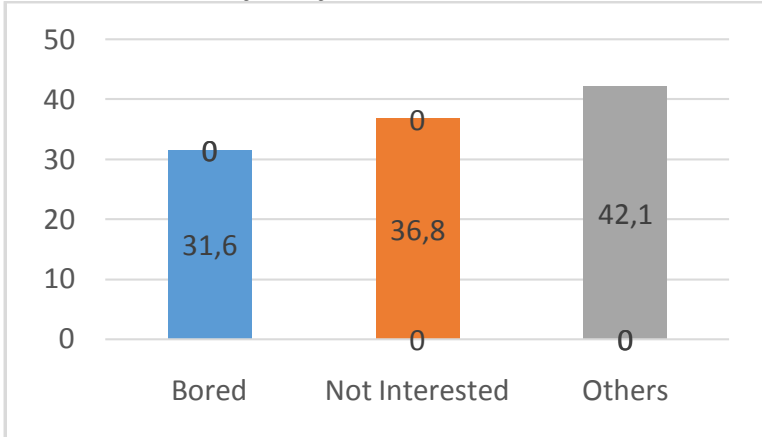

Figure 3.4 Diagram Pre-Test 3

From 38 people who didn't do Brain Gym exercise everyday 31.6 percent (12 people) answers bored, 36.8 percent (14 people) answers not interested, and 42.1 percent (16 people) had other reasons.
3.2.4 Do you like to play video game in your Personal Computer?

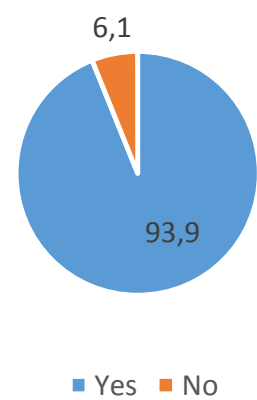

Figure 3.5 Diagram Pre-Test 4

From 98 people, 93.9 percent (92 people) answered yes, and 6.1 percent (6 people) answered no.

\subsubsection{How often do you play on Personal Computer in a week?}

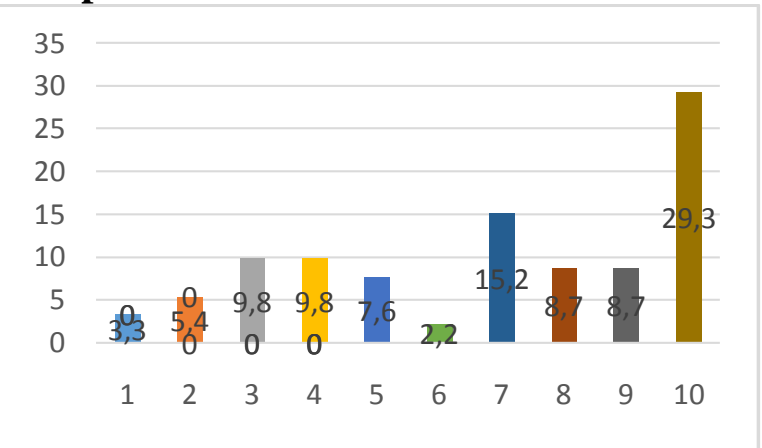

Figure 3.6 Diagram Pre-Test 5

For this question, 29.3 percent played on Personal Computer very often, 15.2 percent played on Personal Computer quite often.

3.2.6 If there is a game could be used for brain balancing do you interested to try?

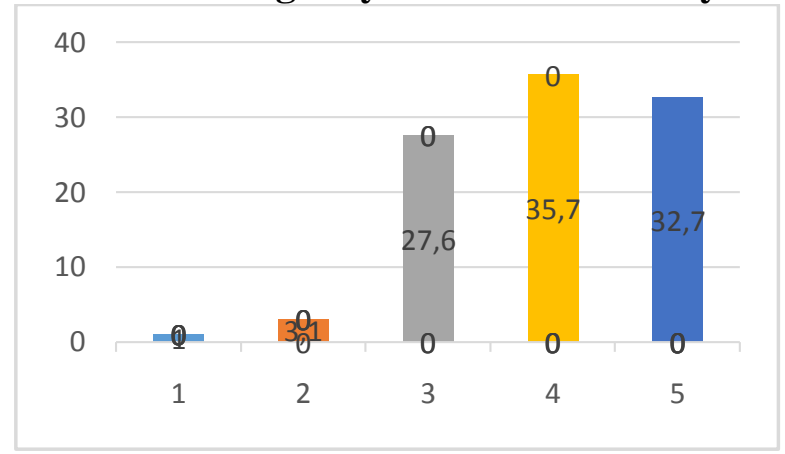

Figure 3.7 Diagram Pre-Test 6

In this question, 32.7 percentwas very interested to try, 35.7 percentwas interested 
to try, and 27.6 percentmight be interested to try.

It can be summarized that most of the subjects know about Brain Gym, but most of them didn't do Brain Gym exercise every day, the reason was indeed bored, not interested, and other reasons. Most of them like to play on Personal Computer and most of them playing every day. And most of them also interested to try game for brain balancing purpose.

\section{RESULT AND DISCUSSION \\ 4.1 Post-Test}

The subject for this test are 35 people either male or female with average age between 15 until 26 years old and already testingTyping Rhythm game.

4.1.1 How much are you interested in Typing Rhythm game?

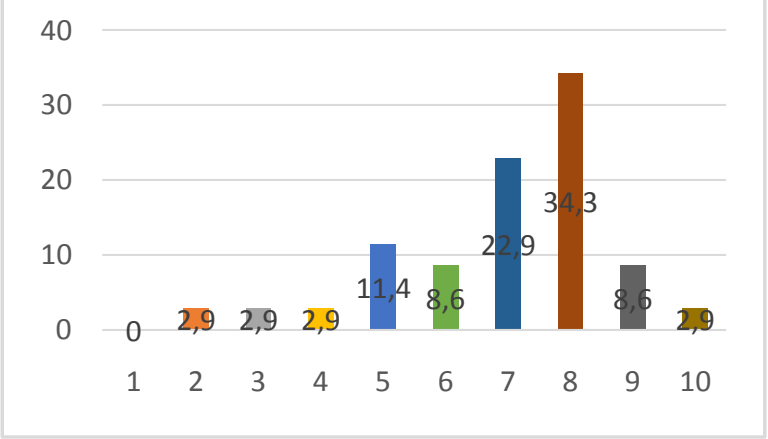

Figure 4.1 Diagram Post-Test 1

In Typing Rhytom game, 34.3 percent (12 people) answers if the game is 80 percent interesting for them and 22.9 percent (8 people) answers if the game is 70 percent interesting for them.

\subsubsection{Do you feel challenged enough when playing this game?}

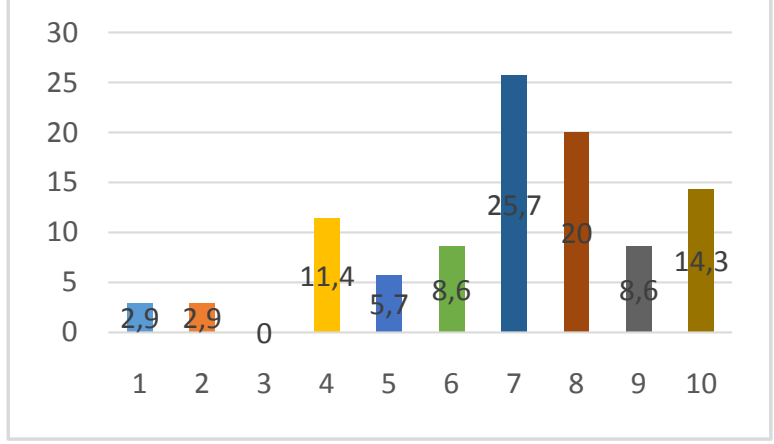

Figure 4.2 Diagram Post-Test 2
From the diagram, 25.7 percent (9 people) answers if the game is 70 percent challenging enough and 20 percent ( 7 people) answers if the game is 80 percent challenging.

\subsubsection{Which part of this game do you like} most?

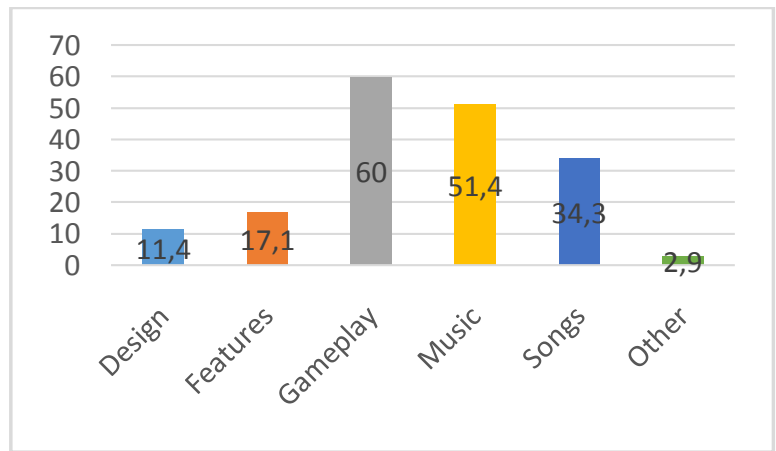

Figure 4.3 Diagram Post-Test 3

The diagram shows that 60 percent (21 people) like the gameplay or the concept of the game. 51.4 percent (18 people) like the background music and the sound effect, and 34.3 percent (12 people) like the available songs.

4.1.3 Do you agree that the combination between song and typing using both hands makes this game interesting?

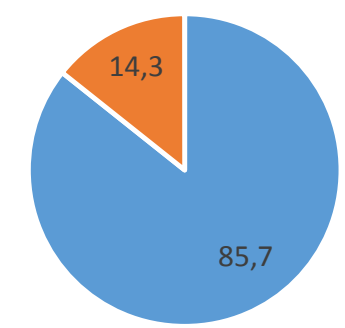

In this question, 85.7 percent (30 people) answers yes, and 14.3 percent (5 people) answers no.

Inconclusion, Typing Rhythm game is interesting; the players are challenged enough when playing this game. From the part of the game the players like the gameplay and the music most. And combination between song and typing using both hands makes this game interesting. 


\section{CONCLUSIONS}

By using music, music can be used to balance brain hemispheres [9]. When we are listening to music or songs we are enjoying the music using right hemisphere and creating emotion, on the other side, the left hemisphere was processing the lyric of the songs [10].

Furthermore by reading we can also be used to balance brain hemispheres. When reading sentences, we are trying to figure out the meaning of every word from the lyric using left hemisphere. After we understand it, we imagine the meaning of the sentences using right hemisphere [8].

Integration movement of fingers from both hands could be used to train both brain hemispheres, because involving the left and right hands [2]. And with the music, music could stimulate both brain hemispheres.

In Typing Rhythm game, the player should type lyric which means that the fingers should active when typing. Moreover, the player is also listening to the song and the lyric from the game. So, from listening to the songs, it could also stimulate the brain.

\section{REFERENCES}

[1] A. N. Chamidah, "Pentingnya Stimulasi Dini Bagi Tumbuh Kembang Otak Anak,” pp. 1-7, 2009.

[2] T. S.Sularyo dan S. Handryastuti, "Senam Otak" Sari Pediatri., vol 4, no. 6, pp. 36-44 2002.
[3] Y. L.S, You Are The Real Personal Success. Jakarta: Elex Media Komputindo, 2010.

[4] R. Taylor, Essay Savvy. Victoria: Purple Parrot Publications, 2001.

[5] A. N. Cahyo, "Game Khusus Penyeimbang Otak Kanan dan Kiri Anak,” Yogyakarta: Flashbooks, 2011.

[6] R. C. Stevens, Bingle Jells: Dyslexia, One Head, Two Brains. 2014.

[7] A. Bennet, D. Bennet, J. Ginsborg, G. Kreutz, and M. Thomas, "The human knowledge system: music and brain coherence," Inf. Knoledge Manafement Syst., vol. 38, no. 4, pp. 277-295, 2008.

[8] Zikwan, “Menyeimbangkan Fungsi Kerja Otak Kanan dan Otak Kiri dalam Pembelajaran Membaca,” 2004.

[9] Hasan, "MEDIA MUSIK ( LAGU ) DALAM PEMBELAJARAN BAHASA Abstrak Jurnal Al-Maqoyis Vol . IV edisi I Januari-Juni 2016 Pendahuluan Jurnal Al-Maqoyis Vol . IV edisi I Januari-Juni 2016,” vol. IV, pp. 53-67.

[10] R. AZIS, “ANALISIS BENTUK DAN STRUKTUR LAGU RED PASHMINA KARYA KELOMPOK KWARTET CELLO FONTICELLO,” pp. 1-8, 2012. 